\title{
Agronomic Evaluation of Groundnut Advanced Varietal Entries with Varieties, Varied Fertilizer Levels and Spacing
}

\author{
V. Vasuki* \\ Department of Agriculture, AEC \& RI, Tamil Nadu Agricultural University, \\ Tiruchirapalli, 621 712, India \\ *Corresponding author
}

\section{A B S T R A C T}

\section{Keywords}

Recommended Dose of fertilizer, Spacing, Advanced varietal trial

Article Info

Accepted: 10 January 2021 Available Online: 10 February 2021
Field experiment was conducted during Rabi/Summer season of 2009-10, 2010-11 and 2011-12, at Coconut Research Station, Aliyarnagar, Tamil Nadu, India, to evaluate the best suited advanced varietal entries for improving pod yield in Pollachi tract of Tamil Nadu. Three factors mainly, Varieties (3), Fertilizer levels (3 viz., $125 \%, 100 \%$ and $75 \%$ of Recommended Dose of Fertilizers, 25:50:75 $\mathrm{kg} \mathrm{ha}^{-1}$ of NPK) and Spacing (two levels, $30 \times 10 \mathrm{~cm}$ and $30 \times 15 \mathrm{~cm}$ ) in Factorial Randomized Block Design (FRBD) with three replications. Results of three years of experimentation with AVT entries J 71 (first year), ICGV 95386 (second year), Dh 216 (third year) are as follows, during first year pod yield recorded with VRI-2 $\left(1751 \mathrm{~kg} \mathrm{ha}^{-1}\right)$ and J-71 $\left(1877 \mathrm{~kg} \mathrm{ha}^{-1}\right)$ were on par with each other followed by ALR-3 (1505 kg ha $\left.{ }^{-1}\right)$. Among different fertilizer levels application of $125 \%\left(1878 \mathrm{~kg} \mathrm{ha}^{-1}\right)$ and $100 \%\left(1831 \mathrm{~kg} \mathrm{ha}^{-1}\right) \mathrm{RDF}$ recorded highest pod yield followed by $75 \%$ of RDF $\left(1425 \mathrm{~kg} \mathrm{ha}^{-1}\right)$. Experimental results of second year revealed that pod yield recorded with medium bold culture ICGV $95386\left(3820 \mathrm{~kg} \mathrm{ha}^{-1}\right)$ was 57.9 and 75.8 per cent higher over TMV $13(2420 \mathrm{~kg}$ $\left.\mathrm{ha}^{-1}\right)$ and VRI-6 (2173 kg ha $\left.{ }^{-1}\right)$, respectively. Application of $125 \% \mathrm{RDF}(3187 \mathrm{~kg} \mathrm{ha}$ $\left.{ }^{1}\right)$ produced 20.9 and 40.7 per cent higher pod yield over RDF $75 \%\left(2034 \mathrm{~kg} \mathrm{ha}^{-1}\right)$ and $100 \%\left(2460 \mathrm{~kg} \mathrm{ha}^{-1}\right)$ and was comparable with each other. Spacing of $30 \times 10 \mathrm{~cm}$ recorded higher pod yield of $3015 \mathrm{~kg} \mathrm{ha}^{-1}$ over spacing of $30 \times 15 \mathrm{~cm}\left(2592 \mathrm{~kg} \mathrm{ha}^{-1}\right)$. During third year experimentation AVT entry Dh 216 recorded higher pod and kernel yield (3216 kg ha ${ }^{-1}, 2189 \mathrm{~kg} \mathrm{ha}^{-1}$ respectively) as compared to VRI 6 (2861 kg ha ${ }^{-1}$, $1757 \mathrm{~kg} \mathrm{ha}^{-1}$ respectively) and TMV 13 (2759 kg ha-1, $1982 \mathrm{~kg} \mathrm{ha}^{-1}$, respectively). Spacing of $30 \times 15 \mathrm{~cm}$ recorded significantly higher pod and kernel yield (3221 kg ha ${ }^{1}$ and $\left.2098 \mathrm{~kg} \mathrm{ha}^{-1}\right)$ as compared to $30 \times 10 \mathrm{~cm}$ spacing $\left(2670 \mathrm{~kg} \mathrm{ha}^{-1}\right.$ and $1725 \mathrm{~kg} \mathrm{ha}^{-1)}$ and application of 75,100 and $125 \%$ of RDF recorded no significant difference among treatments. Among three AVT entries J-71, ICGV 95386 and Dh 216, J-71 experimented agronomically for higher yield, J-71was on par with VRI -2, Medium bold ICGV 95386 and Dh 216 recorded significantly higher yield than the other two high yielding groundnut varieties and were promising for promotion as a high yielding variety. 


\section{Introduction}

Groundnut (Arachis hypogaea L.) is an important oil seed crop of India. In India, Groundnut is cultivated in $26.4 \mathrm{M}$ ha contributing 37.1 million tonnes out of total world production (Central Statistics Office, 2008). Groundnut is known for its rich source of vegetable fats, protein and also for its use as cattle feed and concentrated organic manure.

It can be grown in tropical, sub-tropical and warm temperate regions (Sogut et al., 2016) with average yield of $1520 \mathrm{~kg} \mathrm{ha}^{-1}$ (FAOSTAT, 2011).Choice of the variety plays a significant role in groundnut production. Some of the groundnut varieties have shown that low source and sink relationship resulted in formation of more unfilled pods and lesser seed yield.

Fertility management is another key principle in maximizing groundnut yield. Parasuraman et al., (1998) reported higher availability of plant nutrients consequently had higher growth parameters in the fertilized treatments and higher yield of groundnut. Remunerative responses of groundnut crop to fertilizer application have been observed both under irrigated and rainfed conditions in India (Kanwar et al., 1983). Increase in groundnut yield due to the application of NPK was also reported by Angadi et al., (1990). Plant density is highly associated with yield potential and optimum plant density per unit area is an important non-monetary input to decide the maximum groundnut productivity.

Yield is a function of plant density and there is a considerable scope for increasing the yield by adjusting the plant density to an optimum level (Chaniyara, 2001). Hence, this study was done to evaluate the response of new AVT entries for different spacing and fertilizer levels in comparison with already existing varieties.

\section{Materials and Methods}

Field experiments were conducted at Coconut Research Station, Aliyarnagar during Rabi/Summer 2009-10, 2010-11 and 2011-12 with three different AVT entries namely J-71, ICGV 95386 and Dh 216, respectively. The experimental field soil was sandy clay loam with organic carbon content of $0.25 \%$. The nutrient status of the soil was low in available nitrogen $272 \mathrm{~kg} \mathrm{ha}^{-1}$, medium in available phosphorus $20.6 \mathrm{~kg} \mathrm{ha}^{-1}$ and high in available potassium $420 \mathrm{~kg} \mathrm{ha}^{-1}$ with soil EC of 0.08 $\mathrm{dSm}^{-1}$ and $\mathrm{pH}$ of 7.12. The experiment was laid out in Factorial Randomized Block Design with three replications and plot size of $20 \mathrm{~m}^{-2}\left(4 \times 5 \mathrm{~m}^{-2}\right)$. For fertilizer levels, $100 \%$, $125 \%$ and $75 \%$ of recommended dose of NPK $\left(17: 35: 54 \mathrm{~kg} \mathrm{ha}^{-1}\right)$ were applied as basal. $12.5 \mathrm{t}$ $\mathrm{ha}^{-1}$ of FYM was applied as basal. Gypsum @ of $400 \mathrm{~kg} \mathrm{ha}^{-1}$ was applied in two equal splits of $200 \mathrm{~kg} \mathrm{ha}^{-1}$ as basal and $200 \mathrm{~kg} \mathrm{ha}^{-1}$ as top dressing at 45 DAS during earthing up.

Two different spacing of $30 \times 10 \mathrm{~cm}$ and $30 \mathrm{x}$ $15 \mathrm{~cm}$ were experimented. During first year AVT entry J-71 was compared with VRI 2 and ALR 3, second year AVT entry ICGV 95386 was compared with VRI-6and TMV 13and for third year AVT entry Dh 216 was compared with VRI-6, and TMV 13. The collected data were statistically analyzed using the method Gomez and Gomez (1984) and data interpreted where ever significance observed.

\section{Results and Discussion}

AVT Culture - J-71, Varieties - VRI 2 and ALR 3 (Table 1)

The results of field experiment conducted during 2009-10, recorded that 100 seed weight was significantly highest with ALR-3 (40.2) and VRI 2 (38.1) followed by J-71 (32.5). There was no response for different fertilizer levels. The variety VRI-2 (87.53) and AVT 
entry J-71 (83.62) recorded significantly higher number of pods followed by ALR-3 (79.65). The fertilizer level $125 \%$ (86.67) and $100 \%$ (83.77) RDF recorded highest number of pods followed by $75 \%$ (80.37) of fertilizer RDF.

The shelling percentage was influenced only by different fertilizer levels. The highest shelling percentage was recorded with 125 (62.82) and100 (60.42) \% RDF followed by 75 (53.42) \% RDF. The Pod yield recorded with VRI-2 (1751 kg ha-1) and J-71 (1877 kg $\left.\mathrm{ha}^{-1}\right)$ were on par with each other followed by ALR-3 (1505 kg ha-1).

Among different fertilizer levels the application of $125 \%\left(1878 \mathrm{~kg} \mathrm{ha}^{-1}\right)$ and 100 $\%$ (1831 kg ha $\left.{ }^{-1}\right)$ RDF recorded highest pod yield followed by $75 \%$ of RDF (1425).

For haulm yield in $\mathrm{kg} \mathrm{ha}^{-1}$ the significantly best treatment was ALR-3 (7937 $\left.\mathrm{kg} \mathrm{ha}^{-1}\right)$ followed by VRI-2 (3411 $\left.\mathrm{kg} \mathrm{ha}^{-1}\right)$ and J-71 (3288 $\left.\mathrm{kg} \mathrm{ha}^{-1}\right)$. Among different fertilizer levels $125\left(5376 \mathrm{~kg} \mathrm{ha}^{-1)} \%\right.$ of RDF recorded significantly higher haulm yield followed by $100\left(4825 \mathrm{~kg} \mathrm{ha}^{-1}\right)$ and 75 (4436 kg ha-1)\% of RDF.

The results are in confirmation with the findings of Subrahmaniyan et al., (2000) that increased dose of NPK fertilizers up to 150 per cent of the RDF (26:51:81 $\mathrm{kg}$ NPK ha ${ }^{-1}$ ) recorded significantly higher plant height, greater number of matured pods per plant, higher 100 kernel weight, shelling percentage, sound matured kernel percentage and pod yield of groundnut.

\section{AVT Culture - ICGV 95386, Varieties - VRI 6 and TMV13 (Table 2)}

The results of the field experiment conducted during 2010-2011, revealed that there was significant difference in yield attributes like
Sound matured kernels and shelling percentage.

The varieties VRI 6 (89.1) and TMV 13 (88.8) recorded significantly higher SMK than AVT entry ICGV 95386 (87.2) and were comparable with each other. Application of $125 \%$ RDF registered highest SMK of 92.9 than $100 \%$ (90.0).

Spacing of $60 \times 15 \mathrm{~cm}$ recorded higher SMK (89.8) than $30 \times 15 \mathrm{~cm} \mathrm{(88.3).} \mathrm{Highest}$ shelling percentage was recorded with AVT entry ICGV 95386 (62.62) followed by TMV 13 (60.81) and then by VRI 6 (57.23). $125 \%$ RDF recorded (62.85) higher shelling percentage followed by $100 \%$ RDF (60.24) and $75 \%$ RDF (57.58). The shelling percentage was higher with $30 \times 10 \mathrm{~cm}$ (62.34) than $30 \times 15 \mathrm{~cm}(58.11)$.

ICGV 95386 recorded highest pod weight per plant $15.25 \mathrm{~g}$ followed by TMV $13(9.43 \mathrm{~g})$ and VRI 6 (8.76 g). Similar trend was observed with kernel yield also. ICG 95386 recorded $2402 \mathrm{~kg} \mathrm{ha}^{-1}$ followed by TMV 13 $\left(1486 \mathrm{~kg} \mathrm{ha}^{-1}\right)$ and VRI 6 (1252 kg ha $\left.{ }^{-1}\right) .125$ $\%$ RDF recorded highest kernel yield $(2025 \mathrm{~kg}$ $\mathrm{ha}^{-1}$ ) followed by $100 \%\left(1676 \mathrm{~kg} \mathrm{ha}^{-1}\right)$ and 75 $\%\left(1439 \mathrm{~kg} \mathrm{ha}^{-1}\right)$.

Spacing of $30 \times 10 \mathrm{~cm}$ recorded higher kernel yield of $1899 \mathrm{~kg} \mathrm{ha}^{-1}$ than $30 \times 15 \mathrm{~cm}$ with $1527 \mathrm{~kg} \mathrm{ha}^{-1}$. Pod yield recorded with ICGV $95386\left(3820 \mathrm{~kg} \mathrm{ha}^{-1}\right)$ was 57.9 and 75.8 per cent higher over cv. TMV $13\left(2420 \mathrm{~kg} \mathrm{ha}^{-1}\right)$ and VRI-6 (2173 $\left.\mathrm{kg} \mathrm{ha}^{-1}\right)$, respectively.

The application of $125 \%$ RDF (3187 kg ha ${ }^{-1}$ ) produced 20.9 and 40.7 per cent higher pod yield over RDF $75 \%$ RDF (2034 $\mathrm{kg} \mathrm{ha}^{-1}$ ) and $100 \%\left(2460 \mathrm{~kg} \mathrm{ha}^{-1}\right)$ which is comparable with each other. The spacing of $30 \times 10 \mathrm{~cm}$ recorded higher pod yield of $3015 \mathrm{~kg} \mathrm{ha}^{-1}$ over the spacing of $30 \times 15 \mathrm{~cm}\left(2592 \mathrm{~kg} \mathrm{ha}^{-1}\right)$. 
Table.1 Effect offertilizer levels and spacing on yield parameters of Groundnut AVT entry J -71 and varieties VRI 2 and ALR 3

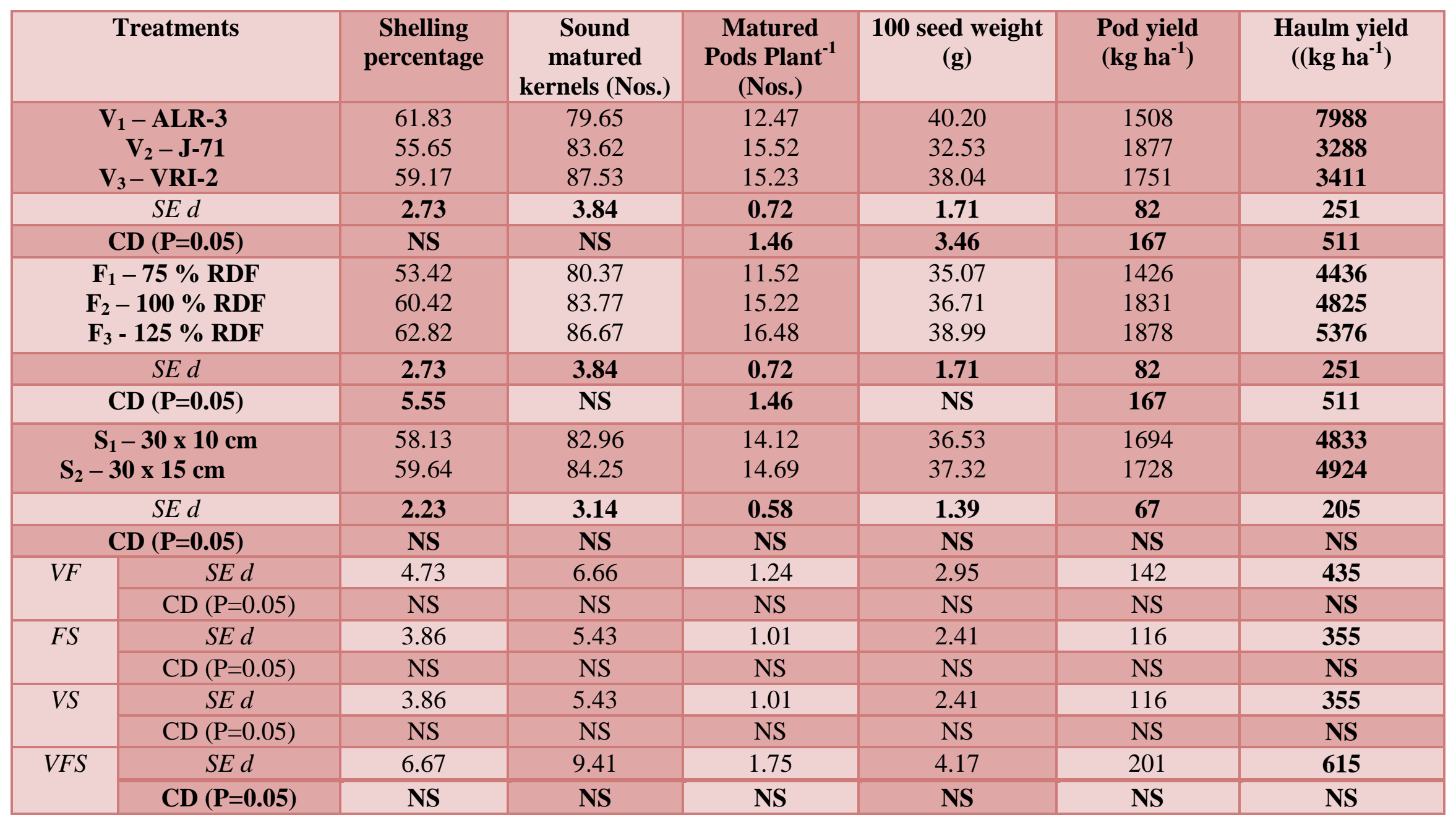


Table.2 Effect of fertilizer levels and spacing on yield parameters of Groundnut AVT entry ICGV 95386 and varieties VRI 6 and TMV 13

\begin{tabular}{|c|c|c|c|c|c|c|c|}
\hline \multicolumn{2}{|c|}{ Treatment } & $\begin{array}{c}\text { Shelling } \\
\text { percentage }\end{array}$ & $\begin{array}{c}\text { Sound } \\
\text { matured } \\
\text { kernels } \\
(\text { Nos.) }\end{array}$ & $\begin{array}{l}\text { Pod weight } \\
\text { plant }^{-1}(g)\end{array}$ & $\begin{array}{l}\text { Kernel yield } \\
\quad\left(\mathrm{kg} \mathrm{ha}^{-1}\right)\end{array}$ & $\begin{array}{l}\text { Pod yield } \\
\left(\mathrm{kg} \mathrm{ha}^{-1}\right)\end{array}$ & $\begin{array}{l}\text { Haulm yield } \\
\qquad\left(\mathrm{kg} \mathrm{ha}^{-1}\right)\end{array}$ \\
\hline \multicolumn{2}{|c|}{$\mathrm{V}_{1}-$ VRI 6} & 57.23 & 88.8 & 8.76 & 1252 & 2172 & 3805 \\
\hline \multicolumn{2}{|c|}{$V_{2}-$ ICGV 95386} & 62.62 & 87.2 & 15.25 & 2402 & 3820 & 4806 \\
\hline \multicolumn{2}{|c|}{$V_{3}-$ TMV 13} & 60.81 & 89.1 & 9.43 & 1486 & 2420 & 4342 \\
\hline \multicolumn{2}{|c|}{ SEd } & 0.62 & 0.9 & 0.51 & 69 & 107 & 108 \\
\hline \multicolumn{2}{|c|}{ CD $(0.05)$} & 1.26 & 1.7 & 1.04 & 141 & NS & 220 \\
\hline \multicolumn{2}{|c|}{$\mathrm{F}_{1}-75 \% \mathrm{RDF}$} & 57.58 & 84.4 & 10.01 & 1439 & 2473 & 3660 \\
\hline \multicolumn{2}{|c|}{$\mathrm{F}_{2}-100 \% \mathrm{RDF}$} & 60.24 & 90.0 & 10.82 & 1676 & 2751 & 4005 \\
\hline \multicolumn{2}{|c|}{$\mathrm{F}_{3}-125 \% \mathrm{RDF}$} & 62.85 & 92.9 & 12.61 & 2025 & 3187 & 4342 \\
\hline \multicolumn{2}{|c|}{ SEd } & 0.62 & 0.85 & 0.51 & 69 & 107 & 108 \\
\hline \multicolumn{2}{|c|}{ CD (0.05) } & 1.26 & 1.73 & 1.04 & 141 & 217 & 220 \\
\hline \multicolumn{2}{|c|}{$S_{1}-30 \times 10 \mathrm{~cm}$} & 62.34 & 88.3 & 12.00 & 1899 & 3015 & 4172 \\
\hline \multicolumn{2}{|c|}{$S_{2}-30 \times 15 \mathrm{~cm}$} & 58.11 & 89.8 & 10.29 & 1527 & 2592 & 3833 \\
\hline \multicolumn{2}{|c|}{ SEd } & 0.51 & 0.70 & 0.42 & 56 & 87 & 88 \\
\hline \multicolumn{2}{|c|}{ CD $(0.05)$} & 1.03 & 1.41 & 0.85 & 115 & 177 & 179 \\
\hline \multirow[t]{2}{*}{ VF } & SEd & 1.07 & 1.48 & 0.89 & 98 & 185 & 187 \\
\hline & $\mathrm{CD}(0.05)$ & NS & NS & NS & NS & NS & NS \\
\hline \multirow[t]{2}{*}{ FS } & SEd & 0.87 & 1.21 & 0.73 & 120 & 151 & 153 \\
\hline & $\mathrm{CD}(0.05)$ & NS & NS & NS & NS & NS & NS \\
\hline \multirow[t]{2}{*}{ VS } & SEd & 0.874 & 1.21 & 0.73 & 98 & 151 & 153 \\
\hline & $\mathrm{CD}(0.05)$ & 1.78 & NS & 1.47 & NS & 307 & 310 \\
\hline \multirow[t]{2}{*}{ VFS } & SEd & 1.51 & 2.09 & 1.26 & 170 & 262 & 264 \\
\hline & CD (0.05) & NS & NS & NS & NS & NS & NS \\
\hline
\end{tabular}


Table.3 Effect of fertilizer levels and spacing on yield parameters of Groundnut AVT entry Dh 216 and varieties VRI 6 and TMV 13

\begin{tabular}{|c|c|c|c|c|c|c|c|}
\hline \multicolumn{2}{|c|}{ Treatment } & $\begin{array}{c}\text { Shelling } \\
\text { percentage }\end{array}$ & $\begin{array}{c}\text { Sound } \\
\text { Matured } \\
\text { kernels (Nos.) }\end{array}$ & $\begin{array}{l}\text { Pod weight } \\
\text { plant }^{-1}(g)\end{array}$ & $\begin{array}{c}\text { Pod yield } \\
\left(\mathrm{kg} \mathrm{ha}^{-1}\right)\end{array}$ & $\begin{array}{l}\text { Kernel yield } \\
\quad\left(\mathrm{kg} \mathrm{ha}^{-1}\right)\end{array}$ & $\begin{array}{l}\text { Haulm yield } \\
\qquad\left(\mathrm{kg} \mathrm{ha}^{-1}\right)\end{array}$ \\
\hline \multicolumn{2}{|c|}{$V_{1}-$ VRI 6} & 60.70 & 93.33 & 20.40 & 2862 & 1757 & 4258 \\
\hline \multicolumn{2}{|c|}{$V_{2}-$ Dh 216} & 67.99 & 95.50 & 24.94 & 3216 & 2189 & 4805 \\
\hline \multicolumn{2}{|c|}{$V_{3}-$ TMV 13} & 64.68 & 95.61 & 19.22 & 2759 & 1788 & 4251 \\
\hline \multicolumn{2}{|c|}{ SEd } & 1.17 & 0.79 & 0.75 & 120 & 88 & 145 \\
\hline \multicolumn{2}{|c|}{ CD (0.05) } & 2.38 & 1.62 & 1.53 & 243 & 179 & 294 \\
\hline \multicolumn{2}{|c|}{$\mathrm{F}_{1}-75 \% \mathrm{RDF}$} & 64.04 & 95.38 & 18.74 & 2917 & 1857 & 4330 \\
\hline \multicolumn{2}{|c|}{$\mathrm{F}_{2}-100 \% \mathrm{RDF}$} & 64.21 & 95.40 & 18.89 & 2852 & 1895 & 4487 \\
\hline \multicolumn{2}{|c|}{$\mathrm{F}_{3}-125 \% \mathrm{RDF}$} & 64.06 & 95.33 & 18.78 & 3068 & 1982 & 4497 \\
\hline \multicolumn{2}{|c|}{ SEd } & 1.17 & 0.79 & 0.75 & 120 & 88 & 145 \\
\hline \multicolumn{2}{|c|}{ CD (0.05) } & NS & NS & NS & NS & NS & NS \\
\hline \multicolumn{2}{|c|}{$S_{1}-30 \times 10 \mathrm{~cm}$} & 63.84 & 94.78 & 20.95 & 2670 & 1724 & 4048 \\
\hline \multicolumn{2}{|c|}{$S_{2}-30 \times 15 \mathrm{~cm}$} & 65.07 & 94.85 & 22.10 & 3221 & 2098 & 4828 \\
\hline \multicolumn{2}{|c|}{ SEd } & 0.95 & 0.65 & 0.61 & 98 & 72 & 118 \\
\hline \multicolumn{2}{|c|}{ CD $(0.05)$} & NS & NS & NS & 199 & 146 & 240 \\
\hline \multirow[t]{2}{*}{ VF } & SEd & 2.02 & 1.38 & 1.30 & 208 & 152 & 250 \\
\hline & $\mathrm{CD}(0.05)$ & 4.12 & $\mathrm{NS}$ & 2.65 & $\mathrm{NS}$ & $\mathrm{NS}$ & NS \\
\hline \multirow[t]{2}{*}{ FS } & SEd & 1.65 & 1.12 & 1.06 & 169 & 124 & 204 \\
\hline & $\mathrm{CD}(0.05)$ & 3.36 & NS & 2.16 & $\mathrm{NS}$ & 253 & NS \\
\hline \multirow[t]{2}{*}{ VS } & SEd & 1.65 & 1.12 & 1.06 & 169 & 124 & 204 \\
\hline & $\mathrm{CD}(0.05)$ & NS & NS & $\mathrm{NS}$ & 344 & 253 & 416 \\
\hline \multirow[t]{2}{*}{ VFS } & SEd & 2.86 & 1.94 & 1.84 & 293 & 215 & 354 \\
\hline & CD (0.05) & NS & NS & NS & NS & NS & NS \\
\hline
\end{tabular}


The reduction in pod yield in $75 \%$ plant density (2.5 lakhs plants ha ${ }^{-1}$ ) with under rows spacing might be due to the cover plant population per unit areas (Kalra et al., 1984). Closer spacing of $30 \times 10 \mathrm{~cm}(100 \%$ plant density) was found to be more economical in groundnut than wider spacing as reported by Ramesh and Sabale, 2001.

AVT Culture - Dh 216, Varieties - VRI 6 and TMV 13 (Table 3)

From the field experiment conducted during 2011-12, the results obtained showed that AVT entry and varieties differed significantly among themselves with pod yield, kernel yield and haulm yield. The shelling percentage recorded with Dh 216 (67.99) was significantly higher than TMV 13 (64.68) and VRI 6 (60.70). Sound matured kernels recorded with TMV 13 (95.61) and Dh 216 (95.50) was higher and comparable with each other followed by VRI 6 (93.33). The pod weight per plant was highest with Dh 216 (24.94 g) followed by TMV 13 (19.22 g) and VRI 6 (20.40 g). The different levels of RDF and spacing recorded no significant difference among themselves for shelling percentage, SMK and pod weight per plant. The AVT entry Dh 216 recorded higher pod and kernel yield(3216 kg ha-, $2189 \mathrm{~kg} \mathrm{ha}^{-1}$, respectively) compared to VRI $6\left(2861 \mathrm{~kg} \mathrm{ha}^{-1}, 1757 \mathrm{~kg} \mathrm{ha}^{-}\right.$ ${ }^{1}$,respectively) and TMV $13\left(2759 \mathrm{~kg} \mathrm{ha}^{-1}\right.$, $1982 \mathrm{~kg} \mathrm{ha}^{-1}, 0.42$, respectively). Groundnut showed good response to wider spacing and no response to different fertilizer levels. Spacing of $30 \times 15 \mathrm{~cm}$ recorded significantly higher pod and kernel yield $\left(3221 \mathrm{~kg} \mathrm{ha}^{-1}\right.$ and $2098 \mathrm{~kg} \mathrm{ha}^{-1}$ ) as compared to $30 \times 10 \mathrm{~cm}$ spacing (2670 kg ha-1 and $1725 \mathrm{~kg} \mathrm{ha}^{-1}$ ). Cultivar Dh 216 produced highest dry pod and kernel yield with wider spacing of $30 \times 10 \mathrm{~cm}$ (3463 kg ha ${ }^{-1}$ and $2501 \mathrm{~kg} \mathrm{ha}^{-1}$, respectively). Similar results of higher pod yield of groundnut due to optimum plant population reported by Agasimani et al., (1984) and
Hameed Ansari et al.,(1993) in concomitant to this result. Application of 75, 100 and $125 \%$ of RDF showed no significant difference among themselves.

The AVT entry J-71 when evaluated with varieties VRI 2 an ALR 3, recorded highest pod yield and was comparable with VRI 2. Among different fertilizer levels the application of $125 \%$ and $100 \%$ RDF recorded highest pod yield followed by $75 \%$ of RDF. Pod yield recorded with ICGV 95386 was 57.9 and 75.8 per cent higher over cv. TMV 13 and VRI-6, respectively. Application of $125 \%$ RDF produced 20.9 and 40.7 per cent higher pod yield over RDF $75 \%$ and 100 $\%$ which is comparable with each other. The spacing of $30 \mathrm{~cm} \times 10 \mathrm{~cm}$ recorded the higher pod yield over the spacing of $30 \times 15 \mathrm{~cm}$. The AVT entry Dh 216 recorded higher pod and kernel yield and higher harvest index compared to VRI 6 and TMV 13. Spacing of $30 \times 15 \mathrm{~cm}$ recorded significantly higher pod and kernel yield as compared to $30 \times 10 \mathrm{~cm}$.

\section{References}

Agasimani, C.A., A.B. Palled, H.D. Naik, and G.K. Kulkarani, 1984. Response of groundnut cultivars to different spacing, Indian Journal of Agronomy, 29 (2):209-212.

Angadi, V.V., S.V. Patil, M.N. Shilvantar, and B.M. Chittapur. 1990. Effect of NPK levels and split application of $\mathrm{N}$ on growth and yield of bunch groundnut in vertisol under irrigation system. Karnataka J. Agric. Sci. 3(1-2): 9- 14.

Central Statistics Office, Ministry of Statistics and Programme Implementation, Govt. of India. Economic Survey of India., Government of India, New Delhi. 2008.

Chaniyara, N.J., R.M. Solanki and V.B. Bhaly, 2001. Response of summer groundnut to spacing and plant 
population. Legume Research, 24: $252-255$.

FAOSTAT. 2011. Production data. http:// faostat.fao.org/2011

Hameed Ansari, A., S.M. Qayym and M. Usman Usmani Khali, 1993. Impact of row spacing and NPK fertilizer levels on the growth, seed yield and seed oil content in peanut (Arachis hypogaea) Oil Crops Newsletter, No.10.

Kalra, G.S., S.T. Thorat and A.B. Pawar, 1984. Response of improved groundnut varieties to different spacing under irrigated condition. Indian. Journal of Agricultural Science, 29(1): 40-42.

Kanwar, J.S., H.L. Nijhawan, and S.K. Raheja. 1983. Groundnut nutrition and fertilizer responses in India. ICAR, New Delhi.

Parasuraman, P., M.N. Budher, P. Manickasundaram and Nandanam, M.
1998. Response of sorghum, finger millet and groundnut to the silt application and combined use of organic matter and inorganic fertilizer under rainfed conditions. Indian $\mathrm{J}$. Agron. 43(3): 528-532

Ramesh, R and R.N., Sabale, 2001. Phosphorus and plant population management in groundnut (Arachis hypogaea) - fenugreek (Trigonella foenum - graecum) - cropping system. Indian J. Agron., 46(4): 621-626.

Sogut T., Ozturk F. and Kizil S. 2016. Agriculture and Agricultural Science Procedia, 10, 76-82.

Subrahmaniyan, K., P. Kalaiselvan, G. Manickam and N. Arulmozhi. 2000. Spacing and fertilizer requirement for confectionery groundnut varieties. Crop Res. 19(2): 210-212

\section{How to cite this article:}

Vasuki, V. 2021. Agronomic Evaluation of Groundnut Advanced Varietal Entries with Varieties, Varied Fertilizer Levels and Spacing. Int.J.Curr.Microbiol.App.Sci. 10(02): 14341441. doi: https://doi.org/10.20546/ijcmas.2021.1002.172 